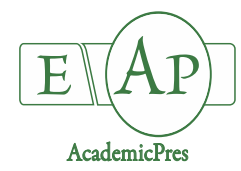

Rukkhun R et al. (2020)
Notulae Botanicae Horti Agrobotanici Cluj-Napoca 48(4):2359-2367
DOI:10.15835/48412045
Research Article

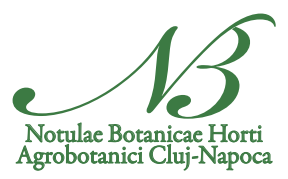

\title{
Effect of high-frequency tapping system on latex yield, tapping panel dryness, and biochemistry of young hillside tapping rubber
}

\author{
Raweerat RUKKHUN ${ }^{1}$, Kesinee IAMSAARD ${ }^{2}$, Sayan SDOODEE ${ }^{1}$, \\ Nipon MAWAN ${ }^{3}$, Nuttapon KHONGDEE ${ }^{4 *}$
${ }^{1}$ Prince of Songkla University, Faculty of Natural Resources, Agricultural Innovation and Management Division (Plant Science), Songkhla, HatYai90110,Thailand; jureerat.ru@psu.ac.th; sayan.s@psu.ac.th
${ }^{2}$ National Chung Hsing University, Department of Soil and Environmental Sciences, Taichung,
Taiwan; kesineeiamsaard@gmail.com
${ }^{4}$ University of Hohenheim, Institute of Agricultural Sciences in the Tropics (Hans-Ruthenberg-Institute), Stuttgart, Germany; nuttaponkhongdee@gmail.com ('correspondingauthor) \\ ${ }^{3}$ Khon Kaen University, Faculty of Agriculture, Department of Agronomy, Khon Kaen, 40002, Thailand; niponma@kkumail.com
}

\begin{abstract}
The objective of this study was to examine the effect of high-frequency tapping system (1/3S $3 \mathrm{~d} / 4)$ on latex yield, biochemistry and its impact on the Tapping Panel Dryness (TPD) of young RRIM600 hillside tapping rubber. The experiment was conducted at three different hillside rubber plantations (NM 1 - 3) at NaMom district, Song Khla province, Thailand. Eight-year-old rubber RRIM 600 clones was used in the experiment starting from 2008 until 2009. The rubber trees were investigated for latex yield production, bark consumption, and TPD. In addition, latex diagnosis (sucrose, inorganic phosphorus ( $\mathrm{Pi}$ ), and thiol levels) was measured. The results demonstrated that high-frequency tapping system positively affected the rubber latex yield formation. However, site-specific condition of rubber plantation altered latex yield production. NM 3 provided the highest latex yield (fresh and dry weight) as compared to other plantations. Tapping frequency was highly correlated to latex yield (fresh and dry weights) in all investigated rubber plantations $\left(\mathrm{R}^{2}>0.75\right)$. Using high-frequency tapping system increased bark consumption and stimulated TPD. Moreover, results of latex diagnosis (sucrose, $\mathrm{Pi}$, and thiol levels) showed relatively unhealthy rubber tree as impacted by highfrequency tapping system. Therefore, the farmer should consider it for better decision-making for tapping system application.
\end{abstract}

Keywords: high-frequency tapping; para rubber; RRIM 600; southern Thailand

\section{Introduction}

Natural rubber, or latex, is a crucial product for many tropical countries, mainly in Asia, South America and some regions of Africa. Most of the latex is mainly produced by smallholder rubber plantations taken more than 2,300,000 ha (Michels et al., 2012). Global demand for natural rubber is being increased yearly (VrignonBrenas et al., 2019). By comparing with synthetic rubber, the demand for natural rubber has increased by $5 \%$ during the last decade, leading to the expansion of rubber tree (Hevea brasiliensis) plantations (Michels et al., 
2012). In Thailand, the southern region is a traditional area for rubber plantation due to high precipitation. Lowland rubber plantation is suitable with rubber latex production; however, rubber has also been expanded planting in hillside area where prone to soil loss and soil degradation. Several studies have shown that high soil moisture status and low vapor pressure favour latex yield (Raj et al., 2005). Therefore, management practices of growers must be more intensive than lowland rubber plantation. Growers need more investment in term of fertilizer inputs and labour costs due to a more laborious task.

In most of the cases, mainly in the southern region of Thailand, there are two significant problems concerning rubber smallholders. Rainfall variation due to climate change trends to occur year-to-year rounds. Heavy rainfall and more rainfall events are leading farmers to use high-frequency tapping systems (HFT) to compensate for the reduction of tapping days due to the rainfall problem (Chantuma et al., 2011). This HFT system may result in overutilization of rubber tree, high rates of tapping panel dryness (TPD), and shorter life of the rubber tree. The insufficient time for latex renewal between successive tapping because of too high tapping frequencies reduces output per tree per tapping (Chantuma et al., 2011).

However, TPD has been considered recently as one of the critical factors limiting rubber productivity (Commère et al., 1989). The cause of TPD has not yet been identified, but many studies have revealed that intensive tapping enhances the occurrence of TPD (Eschbach et al., 1989). Nevertheless, each clone of Hevea brasiliensis has its vulnerability of TPD (Obouayeba et al., 2009). Therefore, the objective of this study was to examine the effect of HFT on latex yield, some biochemical contents and its impact on the TPD of young RRIM600 hillside tapping rubber.

\section{Materials and Methods}

\section{Experimental details}

The experiment on the response of high-frequency tapping system was carried out at the test site of three hillside rubber plantations (NM 1: $\mathrm{N} 06^{\circ} 55^{\prime} 41.4^{\prime \prime} \mathrm{E} 100^{\circ} 32^{\prime} 8.2^{\prime \prime}, \mathrm{NM} 2$ : $\mathrm{N} 07^{\circ} 01^{\prime} 6.8^{\prime \prime} \mathrm{E} 100^{\circ} 35^{\prime} 8.8^{\prime \prime}$ and

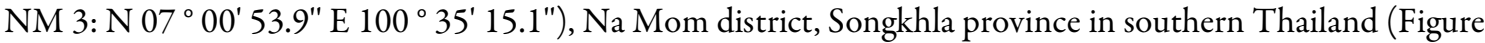
1a). This region is categorized as a subtropical area with two distinct seasons (dry and rainy seasons) (Sternstein, 1962; Thai Meteorological Department, 2013). The dry season is from mid-February to mid-May, and the rainy season is from mid-May to mid-February (Sainoi et al., 2017) (Figure 2b). Rubber RRIM 600 clone was used in the experiment. The soil type in the hillside area is loamy sand (coated, isohyperthermic, typic quartzipsamments) (Soil Survey Staff, 2014). Soil properties at the test site of three rubber plantation are presented in Table 1 . This rubber clone was planted with the spacing of $7 \times 3 \mathrm{~m}$ in the year 2000 . The experiment was started in August of 2008 with 8-year-old trees. The trees were selected before tapping based on the homogenous girth of the trunk and open for tapping at $1.50 \mathrm{~m}$ from the ground on panel A. The tapping notations were arranged according to the Revised International Notation for Latex Harvest Technology (Vijayakumar et al., 2009). The tapping system was $1 / 3 \mathrm{~S} 3 \mathrm{~d} / 4$ (three half spiral cut tapped every four days), and tapping details are presented in Table 2. Plantation 1 (NM 1) was two rows of trees, used 120 trees. Plantation 2 (NM 2) was three rows of trees, used 68 trees. Plantation 3 (NM 3) was six rows of trees, used 78 trees.

\section{Data collection and analysis}

The latex yield data were recorded every tapping day of fresh weight per day. Latex yield data were converted into dry weight rubber production as follows:

Dry weight rubber production $(\mathrm{kg})=$ Latex fresh weight $(\mathrm{kg}) \mathrm{x} \%$ Dry rubber content $(\mathrm{w} / \mathrm{w})$

Then, the latex yield in each rubber plantation was calculated and expressing it as kilograms per tree. Rubber bark consumption (in centimetres) was determined on the tapped panel every 3 months from the beginning to the end of the tapping period. Latex biochemistry or latex diagnosis was assessed every month and 
reported as the average values from the beginning to the end of the month. Sampling position was applied on the rubber trunk at the middle of the cut, approximately $5 \mathrm{~cm}$ below tapping cut (downward tapping). Pooled latex sampling was applied (Jacob et al., 1989). The latex biochemical parameters were measured for the sucrose content, inorganic phosphorus content and reduced thiol content as micromoles and were analysed according to the method developed by CIRAD and CNRA and adapted in 1995 by IRRDB (Jacob et al., 1988). Tapping panel dryness (TPD) was done twice in May and February. Trees that exude latex on the whole length of the panel after tapping were considered as " healthy" trees and noted zero $(0)$. The others were considered as trees affected by tapping panel dryness and noted from 1 to 6 according to the latex non-producing panel length. Thus, the following classes of percentages of latex non-producing panel length were classified as follows:- Level $1=1$ to $20 \%$ trees affected by TPD of very weak level; level $2=21$ to $40 \%$ trees affected by TPD of weak level; level $3=41$ to $60 \%$ trees affected by TPD of middle level; level $4=61$ to $80 \%$ trees affected by TPD of enough high level; level $5=81$ to $99 \%$ trees affected by TPD of high level and level $6=100 \%$ trees affected by total TPD or dry trees.
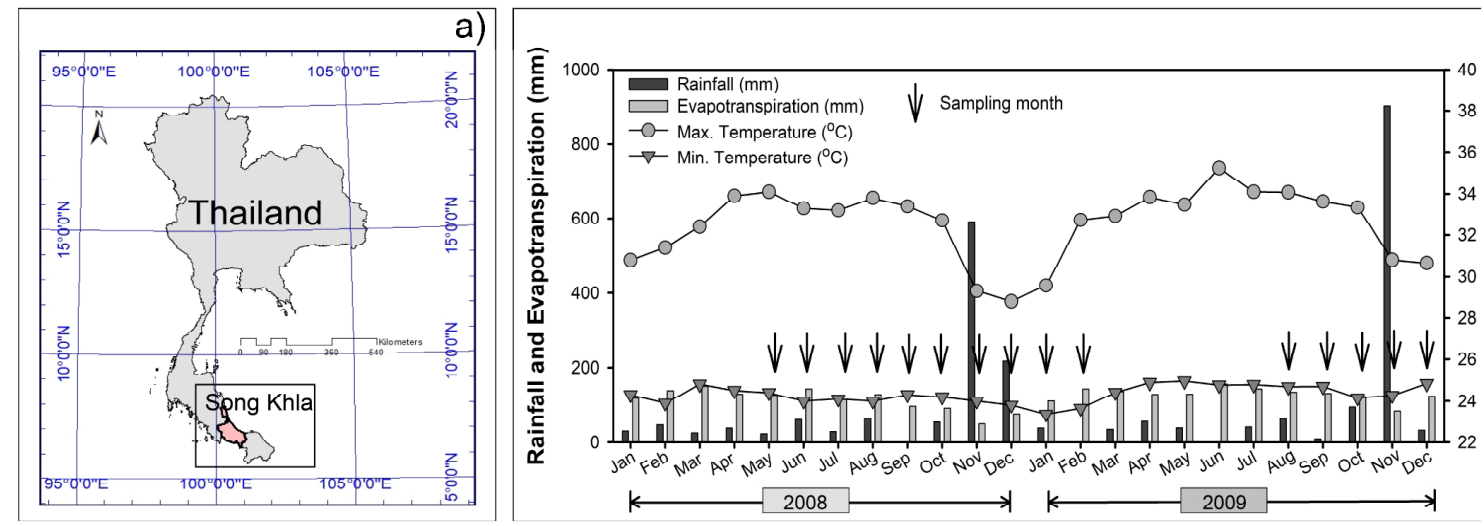

Figure 1. Localization (a), climatic condition and sampling calendar (b) of hillside rubber plantation

Table 1. Soil properties at the test site of three hillside rubber plantations

\begin{tabular}{|c|c|c|c|c|c|}
\hline \multirow{2}{*}{ Locations } & \multicolumn{5}{|c|}{ Soil properties } \\
\cline { 2 - 6 } & Soil texture & $\mathrm{N}(\%)$ & $\mathrm{P}\left(\mathrm{mg} \mathrm{kg}^{-1}\right)$ & $\mathrm{K}\left(\mathrm{mg} \mathrm{kg}^{-1}\right)$ & $\mathrm{pH}$ \\
\hline NM 1 & Loamy sand & 0.05 & 12.05 & 33.31 & 5.81 \\
\hline NM 2 & Loamy sand & 0.05 & 3.83 & 47.71 & 5.64 \\
\hline NM 3 & Loamy sand & 0.04 & 3.38 & 15.70 & 6.14 \\
\hline
\end{tabular}

Table 2. Tapping sequences of three experiments site by (1/3S 3d/4) tapping system

\begin{tabular}{|c|c|c|c|c|c|c|c|}
\hline $\begin{array}{c}\text { Tapping } \\
\text { frequency }\end{array}$ & Mon & Tue & Wed & Thu & Fri & Sat & Sun \\
\hline NM 1 & $\mathrm{T}$ & $\mathrm{T}$ & $\mathrm{T}$ & Stop & $\mathrm{T}$ & $\mathrm{T}$ & $\mathrm{T}$ \\
\hline NM 2 & $\mathrm{T}$ & $\mathrm{T}$ & $\mathrm{T}$ & Stop & $\mathrm{T}$ & $\mathrm{T}$ & $\mathrm{T}$ \\
\hline NM 3 & $\mathrm{T}$ & $\mathrm{T}$ & $\mathrm{T}$ & Stop & $\mathrm{T}$ & $\mathrm{T}$ & $\mathrm{T}$ \\
\hline
\end{tabular}

Note: 1/3S 3d/4; Third spiral cut downward at third daily tapping (T), three days in tapping followed by one day of tapping rest (Stop) in four days

\section{Results and Discussions}

Latex yield production and its relationship with tapping frequency

Latex yield formation of rubber tree begins with the conversion of photosynthesis outcomes, assimilates as the sucrose are changed into the glucose. Polysaccharides as sucrose are inside the latex vessels (Lacote et al., 
2004). High-frequency tapping system showed high latex yield outcomes. Purwaningrum et al. (2019) also stated that tapping frequency has a significant effect on the latex yield. Fig. 2 shows fresh and dry weights of rubber latex harvested from three hillside rubber plantations in traditional rubber plantation area of 2008 and 2009. Rubber latex fresh and dry weights of 2009 was significantly higher than in 2008. Rubber latex production is driven by rubber age increment (Purwaningrum et al., 2019). However, site-specific condition of rubber plantation affected in different latex yield formations. NM 3 provided the highest latex yield (fresh and dry) as compared to other plantations. Fresh weight of these three plantations in 2009 was in the range of 0.12 to $0.14 \mathrm{~kg} \mathrm{tree}^{-1}$ tapping ${ }^{-1}$, whereas dry weight was in the range of 0.035 to $0.044 \mathrm{~kg} \mathrm{tree}^{-1}$ tapping $^{-1}$. Latex fresh weight contained about $67-71 \%$ of water as clearly seen in the yield difference between fresh and dry weights. Increases of latex yield corresponded well with tapping frequency. Sainoi et al. (2017) compared between lowfrequency tapping and high-frequency tapping systems applied to young-tapped rubber trees in southern Thailand; however, high-frequency tapping system showed higher latex yield per tree per tapping.

Figure 3 reveals the relationship between latex yield and tapping frequency of each rubber plantation. It was clearly seen that rubber latex yield had a strong relationship with tapping frequency.

\section{Effect of high frequency tapping on rubber bark consumption and tapping panel dryness}

The average bark consumption was significantly different among the three rubber plantations (Figure 4), with NM 3 having the highest $(3 \mathrm{~cm})$ whereas NM 2 had the lowest bark consumption $(1.8 \mathrm{~cm})$. Results showed that the rate of TPD is insignificantly different among the three rubber plantations even though numbers of tapping were different in each rubber plantation. These results confirmed the conclusion of Obouayeba et al. (2006) as mentioned by Purwaningrum et al. (2019) study showing that the susceptibility to tapping panel dryness and tapping systems were both linked in several clones, i.e. RRIM 600 and PB 235. However, the occurrence and severity of tapping panel dryness depend strongly on tapping systems frequency. Therefore, TPD probably can be reduced by low tapping frequency (Traoré et al., 2011).

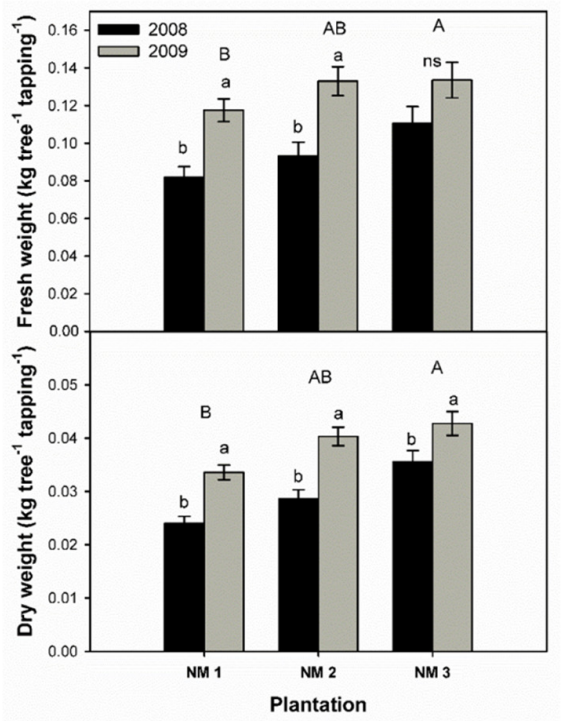

Figure 2. Latex yield (fresh weight, and dry weight) of three different rubber plantations tapped by highfrequency tapping system

Note: $\mathrm{a}$ and $\mathrm{b}$ represent significant differences at $\mathrm{P}<0.05$ among years, and $\mathrm{A}$ and $\mathrm{B}$ represent significant differences at $\mathrm{P}<0.05$ among rubber plantations, Error bars represents Standard Error $(\mathrm{SE})$ 


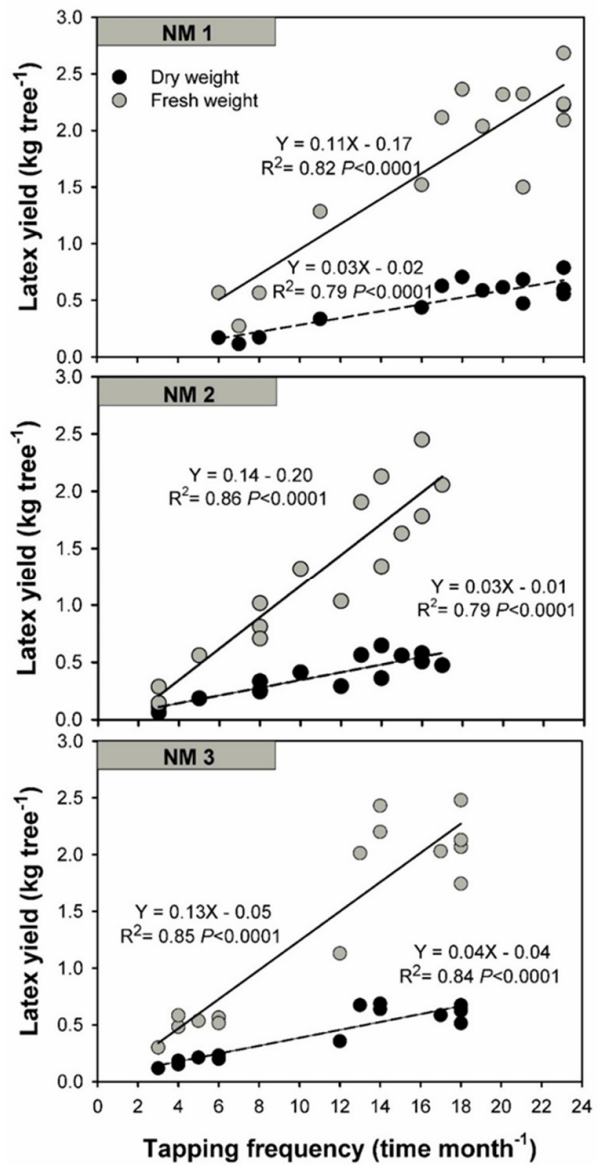

Figure 3. Relationships between rubber latex yield (dry and fresh weights) and tapping frequency of three different rubber plantations

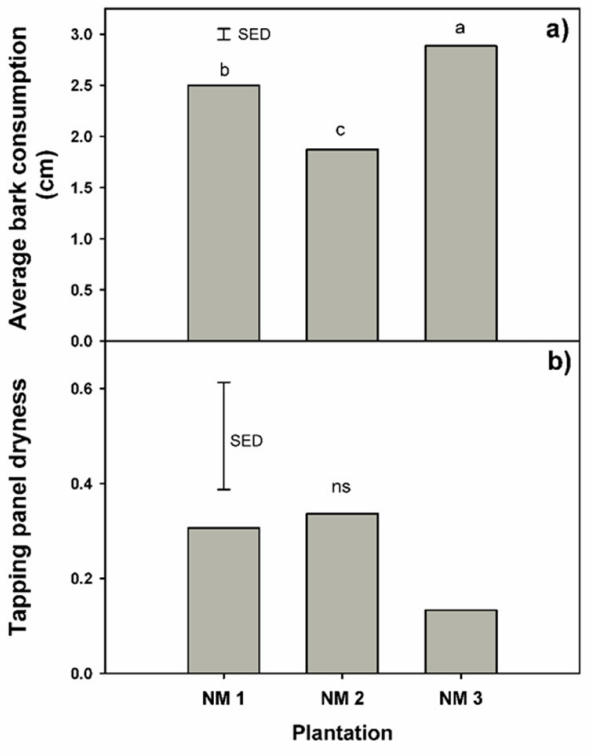

Figure 4. Average bark consumption and tapping panel dryness as affected by high-frequency tapping system 


\section{Effect of high-frequency tapping system on rubber latex biochemistry}

Latex diagnosis determines rubber tree physiology by the applied exploitation system (Traoré et al., 2011), including sucrose, inorganic phosphorus, and thiol latex. Sucrose is needed by latex cells for latex regeneration (Conte and Carroll, 2013). The tapping frequency affected the latex sucrose levels of clone RRIM 600 (Table 3). Similarly, Purwaningrum et al. (2019) revealed that tapping frequency impacted sucrose level of PB 260. The highest sucrose level $(13.06 \mathrm{mM})$ was obtained in NM 2 of 2009 , while the lowest sucrose level $(6.43 \mathrm{mM})$ was obtained in NM 2 of 2008.

Inorganic $\mathrm{P}(\mathrm{Pi})$ is an indicator of metabolic activity of the rubber tree. It shows the potential of rubber tree to convert raw materials (sucrose) into rubber particles (Jacob et al., 2018). The optimal Pi concentration range is from 10 to $30 \mathrm{mM}$ (Purwaningrum et al., 2019). The frequency of tapping had a significant effect on the latex Pi levels of RRIM 600 (Table 3). The highest Pi concentration $(18.99 \mathrm{mM})$ was obtained in NM 1 of 2009, and the lowest Pi was found in NM 3 of 2008. It was noticeably that Pi levels were lower than the optimum Pi level in some rubber plantations and years. Therefore, high-frequency tapping system may reduce Pi level of rubber latex.

In the latex diagnosis, sucrose and Pi level investigation are more potent when combined with thiol level measurements because it reflects the ability of latex vessels to deal with ageing mechanisms (Purwaningrum et al., 2019). Thiol availability in latex is essential for plants because it functions as an enzyme activator to prolong latex flow (Gao et al., 2006). Thiol content was found highest in NM 1 of 2009. However, the high-frequency tapping system is still at a safe level in NM 1 and NM 3 of 2009 and does not cause stress because of the thiol level. According to Sumarmadji and Junaidi (2008), as mentioned in (Purwaningrum et al., 2019), the optimal thiol level ranges from 0.4 to $0.9 \mathrm{mM}$. Increasing the exploitation intensity by high-frequency tapping system affects increased thiol level, but in the case of overexploitation, thiol levels decrease (Gao et al., 2006).

\section{Principal component analysis of rubber factors as affected by high-frequency tapping system}

Principal component analysis of rubber factors influenced by high-frequency tapping system demonstrated that all of the rubber factors positively correlated with tapping frequency as indicated by PC1 (61.50\%) (Figure 5). Latex dry and fresh weights were closest related to tapping frequency, and sucrose and thiol contents were the highest distant relation to tapping frequency.

Table 3. Biochemical contents in rubber latex of three hillside rubber plantations under high-frequency tapping system

\begin{tabular}{|c|c|c|c|c|}
\hline \multirow{2}{*}{ Locations } & \multirow{2}{*}{ Year } & \multicolumn{3}{|c|}{ Biochemical contents (mM) } \\
\cline { 3 - 5 } & & Sucrose & Inorganic Phosphorus & Thiol Content \\
\hline \multirow{2}{*}{ NM 1 } & 2008 & 11.89 & 11.20 & 0.23 \\
\cline { 2 - 5 } & 2009 & 11.74 & 18.99 & 0.56 \\
\hline \multirow{2}{*}{ NM 2 } & 2008 & 6.43 & 8.36 & 0.33 \\
\cline { 2 - 5 } & 2009 & 13.06 & 15.20 & 0.25 \\
\hline \multirow{2}{*}{ NM 3 } & 2008 & 8.48 & 7.76 & 0.33 \\
\cline { 2 - 5 } & 2009 & 9.59 & 16.34 & 0.52 \\
\hline
\end{tabular}




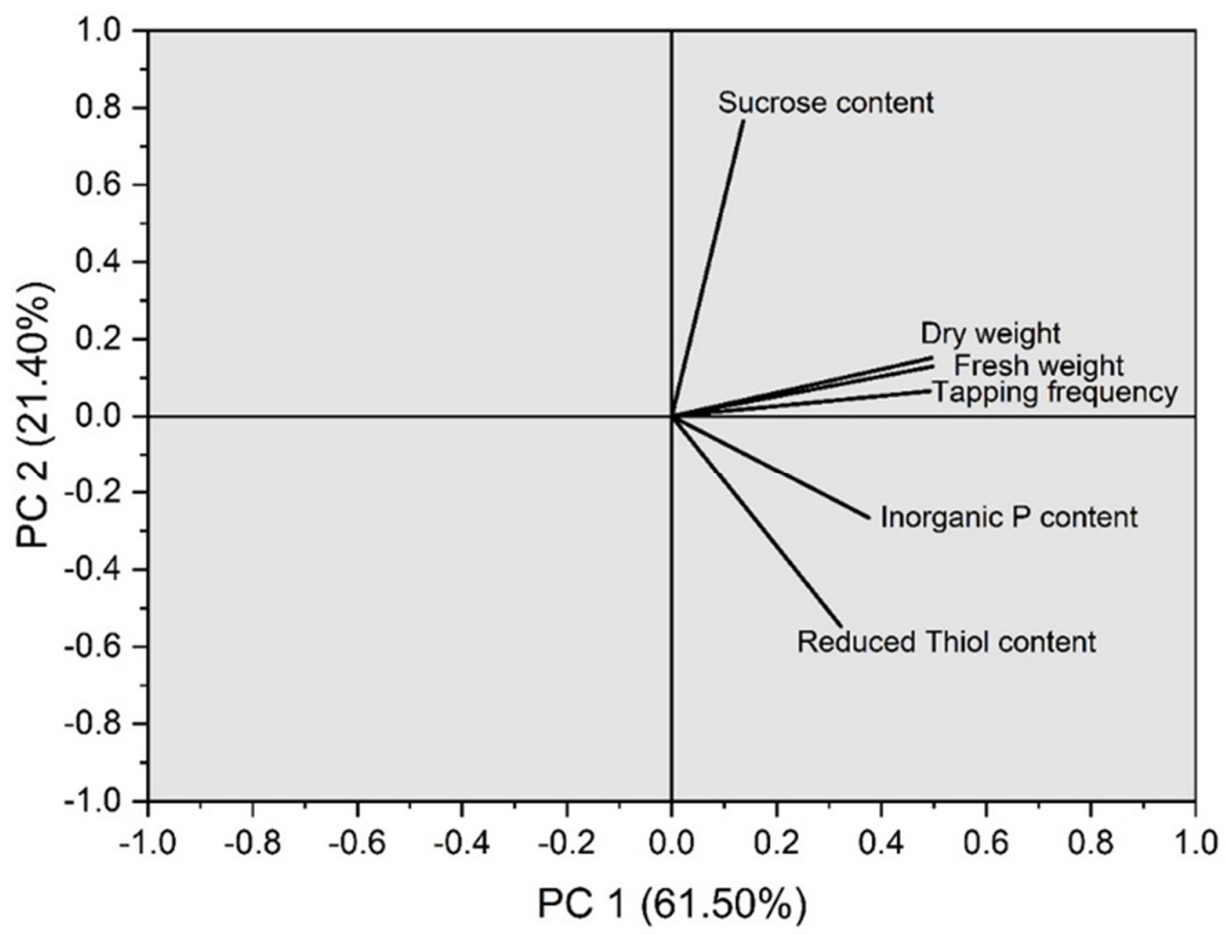

Figure 5. Principal Component Analysis of rubber factors as affected by high-frequency tapping system

\section{Conclusions}

High-frequency tapping system $(1 / 3 \mathrm{~S} 3 \mathrm{~d} / 4)$ positively affected the rubber latex yield formation. However, site-specific condition of rubber plantation altered latex yield production. NM 3 provided the highest latex yield (fresh and dry weight) as compared to other plantations. Tapping frequency was highly correlated to fresh and dry weights in entirely rubber plantations $(\mathrm{R} 2>0.75)$. Using high-frequency tapping system increased bark consumption and stimulated TPD. Moreover, results of latex diagnosis (sucrose, Pi, and thiol levels) showed relatively unhealthy rubber tree as impacted by high-frequency tapping system. Therefore, the farmer should consider it for better decision-making for tapping system application.

\section{Authors' Contributions}

This work was conducted by Raweerat Rukkhun under the supervision of Assoc. Prof. Dr. Sayan Sdoodee. All data from the experiment were analysed by Nattapon Khongdee. After that, Kesinee Iamsaard and Nipon Mawan were responsible for the manuscript preparation. All authors read and approved the final manuscript.

\section{Acknowledgements}

This work was supported by higher education research promotion under the National Research University Project of Thailand, Office of the Higher Education Commission. This research was conducted under the Heavea Research Platform in Partnership (HRPP), Thailand. Moreover, authors would like to 
acknowledge Prince of Songkla University for providing research grant to conduct this research and all involved rubber farmers for their supports.

\section{Conflict of Interests}

The authors declare that there are no conflicts of interest related to this article.

\section{References}

Chantuma P, Lacote R, Leconte A, Gohet E (2011). An innovative tapping system, the double cut alternative, to improve the yield of Hevea brasiliensis in Thai rubber plantations. Field Crops Research 121(3):416-422. https://doi.org/10.1016/j.fcr.2011.01.013

Commère J, Eschbach JM, Serres E (1989). Tapping panel dryness in Côte d'Ivoire. Proc. Workshop on tree dryness, 2627 June 1989, Penang, Malaysia pp 83-98.

Conte ML, Carroll KS (2013). The chemistry of thiol oxidation and detection. In: Oxidative Stress and Redox Regulation. https://doi.org/10.1007/978-94-007-5787-5_1

de Souza Gonçalves P, Bortoletto N, Cardinal ÁBB, Gouvêa LRL, da Costa RB, de Moraes MLT (2005). Age-age correlation for early selection of rubber tree genotypes in São Paulo State, Brazil. Genetics and Molecular Biology 28(4):758-764. https://doi.org/10.1590/s1415-47572005000500018

Eschbach JM, Lacrotte R, Serres E (1989). Conditions which favor the onset of brown bast. In: Physiology of rubber tree latex. d'Auzac JL, Chrestin JH (Eds). Proceeding of CRC Press, Boca Raton pp 443-458.

Gao H, Shupe TF, Hse CY, Eberhardt TL (2006). Antioxidant activity of extracts from the bark of Chamaecyparis lawsoniana (A. Murray) Parl. Holzforschung 60(4):459-462. https://doi.org/10.1515/HF.2006.073

Jacob JL, Serres E, Prévôt JC, Lacrotte R, Vidal A, Eschbach JM, d'Auzac J (1988). Development of Hevea latex diagnosis. Agritrop 12:97-115.

Jacob JL, Prévôt JC, Roussel D, Lacrotte R, Serres E, D'Auzac J, ... Omont H (1989). Yield limiting factors, latex physiological parameters, latex diagnosis, and clonal typology. CRC Press.

Jacob JL, Prévôt JC, Kekwick RGO (1989). General metabolism of Hevea brasiliensis latex (with the exception of isoprenic anabolism). In: Physiology of Rubber Tree Latex: The Laticiferous Cell and Latex-A Model of Cytoplasm. CRC Press

Lacote R, Obouateba S, Clement-Demange A, Dian K, GnaGne M, Gohet E (2004). Panel management in rubber (Hevea brasiliensis) tapping and impact on yield, growth and latex diagnosis. Journal of Rubber Research 7:199-217.

Michels T, Eschbach JM, Lacote R, Benneveau A, Papy F (2012). Tapping panel diagnosis, an innovative on-farm decision support system for rubber tree tapping. Agronomy for Sustainable Development 32:791-801. https://doi.org/10/1007/s13593-011-0069-2

Obouayeba S, Coulibaly LF, Gohet E, Yao TN, Ake S (2009). Effect of tapping systems and height of tapping opening on clone PB 235 agronomic parameters and it's susceptibility to tapping panel dryness in south-east of Côte d' Ivoire. Journal of Applied Biosciences 24:1535-1542.

Purwaningrum Y, Asbur Y, Junaidi (2019). Latex quality and yield parameters of Hevea brasiliensis (Willd. ex A. Juss.) Müll. Arg. clone PB 260 for different tapping and stimulant application frequencies. Chilean Journal of Agricultural Research 79(3):347-355. https://doi.org/10.4067/S0718-58392019000300347

Raj S, Das G, Pothen J, Dey SK (2005). Relationship between latex yield of Hevea brasiliensis and antecedent environmental parameters. International Journal of Biometeorology 49(3):189-196. https://doi.org/10.1007/s00484-004-0222-6

Sainoi T, Sdoodee S, Lacote R, Gohet E (2017). Low frequency tapping systems applied to young-tapped trees of Hevea brasiliensis (Willd. ex A. Juss.) Müll. Arg. in Southern Thailand. Agriculture and Natural Resources 51(4):268272. https://doi.org/10.1016/j.anres.2017.03.001

Soil Survey Staff (2014). Keys to soil taxonomy by soil survey staff, 12th edition. Soil Conservation Service.

Sternstein L (1962). The rainfall of Thailand “a study by Lawrence Sternstein” supported by the U.S. Army quartermaster corps. Research and Engineering Command. Project No. 7-83:01-006. 
Thai Meteorological Department (2013). World's seasons. Thai Meteorological Department. Bangkok, Thailand.

Traoré M, Diarrassouba M (2011). Long-term effect of different annual frequencies of ethylene stimulation on rubber productivity of clone GT 1 of Hevea brasiliensis (Muell. Arg.) in South East of Côte d'Ivoire. Agriculture and Biology Journal of North America 2(8):1251-1260. https://doi.org/10.5251/abjna.2011.2.8.1251.1260

Vijayakumar KR, Gohet E, Thomas KU, XiaodiW, Lakshman R, Sopchoke P., ... Mohd Akbar S (2009). Revised international notation for latex harvest technology. https://doi.org/10.13140/RG.2.1.1298.5048

Vrignon-Brena S, Gay F, Ricard S, Snoeck D, Perron T, Mareschal L, ... Malagoli P (2019). Nutrient management of immature rubber plantations. A review. Agronomy for Sustainable Development 39(1):11. https://doi.org/10.1007/s13593-019-0554-6

OPEN ACCESS

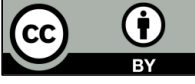

The journal offers free, immediate, and unrestricted access to peer-reviewed research and scholarly work. Users are allowed to read, download, copy, distribute, print, search, or link to the full texts of the articles, or use them for any other lawful purpose, without asking prior permission from the publisher or the author.

License - Articles published in Notulae Botanicae Horti Agrobotanici Cluj-Napoca are Open-Access, distributed under the terms and conditions of the Creative Commons Attribution (CC BY 4.0) License.

(C) Articles by the authors; UASVM, Cluj-Napoca, Romania. The journal allows the author(s) to hold the copyright/to retain publishing rights without restriction. 